Article

\title{
Studies on Pounding Response Considering Structure-Soil-Structure Interaction under Seismic Loads
}

\author{
Peizhen $\mathrm{Li}^{1,2}$ (D), Shutong Liu ${ }^{2}$ and Zheng Lu ${ }^{1,2, *}$ \\ 1 State Key Laboratory of Disaster Reduction in Civil Engineering, Tongji University, Shanghai 200092, China; \\ lipeizh@tongji.edu.cn \\ 2 Research Institute of Structural Engineering and Disaster Reduction, Tongji University, Shanghai 200092, \\ China; liushutong@tongji.edu.cn \\ * Correspondence: luzheng111@tongji.edu.cn; Tel.: +86-21-6598-6186
}

Received: 23 November 2017; Accepted: 28 November 2017; Published: 1 December 2017

\begin{abstract}
Pounding phenomena considering structure-soil-structure interaction (SSSI) under seismic loads are investigated in this paper. Based on a practical engineering project, this work presents a three-dimensional finite element numerical simulation method using ANSYS software. According to Chinese design code, the models of adjacent shear wall structures on Shanghai soft soil with the rigid foundation, box foundation and pile foundation are built respectively. In the simulation, the Davidenkov model of the soil skeleton curve is assumed for soil behavior, and the contact elements with Kelvin model are adopted to simulate pounding phenomena between adjacent structures. Finally, the dynamic responses of adjacent structures considering the pounding and SSSI effects are analyzed. The results show that pounding phenomena may occur, indicating that the seismic separation requirement for adjacent buildings of Chinese design code may not be enough to avoid pounding effect. Pounding and SSSI effects worsen the adjacent buildings' conditions because their acceleration and shear responses are amplified after pounding considering SSSI. These results are significant for studying the effect of pounding and SSSI phenomena on seismic responses of structures and national sustainable development, especially in earthquake prevention and disaster reduction.
\end{abstract}

Keywords: pounding; impact; structure-soil-structure interaction; dynamic response; seismic loads

\section{Introduction}

In recent decades, with urbanization, city blocks containing clusters of closely spaced buildings are becoming more prevalent. Under strong earthquakes, as a result of different structural dynamic characteristics, out of phase lateral vibrations are generally induced. The buildings cannot vibrate freely since the separation distance between adjacent buildings is not sufficient, then pounding arises. The short duration and high magnitude of acceleration pulses generated by the pounding effect may bring about severe damages. Pounding damages have been observed and reported in recent earthquakes (the 1989 Loma Prieta Earthquake [1], the 2010 Darfield Earthquake [2], Christchurch earthquake in 2011 [3]). Furthermore, there is an influence on the dynamic characteristics and the earthquake responses between closely spaced buildings, called Structure-Soil-Structure Interaction (SSSI). Therefore, studying pounding between adjacent buildings considering SSSI is of great importance to predict seismic responses of structures.

Earthquake prevention and disaster reduction is a national strategy of China. It is important to sustainable development. Many structural control devices are accordingly studied [4-10]. To prevent structure collapse [11] and minimize the loss of earthquake disasters, "Earthquake Disaster Prevention and Reduction Plan (2016-2020)" has been implemented in China now, a primary task of which is 
enhancing the resistance to earthquake disaster. If pounding occurs between adjacent structures during earthquake, it would aggravate the structural damages. Then tremendous losses on economy and people's lives, etc., would be caused, which is detrimental to the sustainable development of country. Accordingly, studying pounding between adjacent buildings considering SSSI is of great importance to the sustainable development of whole country.

Some interrelated research in theoretical studies and numerical analysis has recently received attention. Anagnostopoulos et al. [12] developed equivalent viscous damping to build inelastic effects during pounding under seismic excitation. Muthukumar et al. [13] studied the seismic pounding response of adjacent buildings applying various impact models and introduced Hertz damp model for pounding impacts. Naserkhaki et al. [14] used a visco-elastic contact model to simulate the pounding force for adjacent buildings resting on the soil. Naderpour et al. [15] presented the nonlinear viscoelastic model of impact force with the considered relation between the coefficients of restitution and damping. Padron et al. [16] addressed the influence of SSSI on shear forces, lateral spectral deformations, etc., via BEM-FEM (Boundary element method-finite element method) and found SSSI influences groups of structures with similar dynamic characteristics. Ghergu et al. [17] developed a completely coupled structure-soil-structure model to study the interaction between the buildings. Alamo et al. [18] studied SSSI impacts on the responses of nearby piled structures under obliquely incident shear waves using BEM-FEM. Madani et al. [19] addressed impact of soil flexibility (SSSI) on the resultant of pounding forces using Opensees.

Some experiments have also been conducted to study actual pounding impacts between buildings. Filiatrault et al. [20] made shake table tests of pounding between adjacent unequal-height steel framed model structures. Chau et al. [21] designed shake table tests of two steel towers whose natural frequencies and damping ratios are different to study the pounding phenomenon, under different combinations of stand-off distance and seismic excitations. Rezavandi et al. [22] conducted two sets of shake table tests on small scale moment resisting one-bay frames under harmonic excitations, presenting techniques to reduce the pounding effects. Jankowski et al. [23] suggested appropriate formulations in the numerical analysis during pounding, based on shaking table tests concerning interactions between elements made of different building materials.

Although some studies have been conducted on pounding effects both in numerical simulation and experimental study, investigation on pounding response considering SSSI is seldom carried out, especially on combination with a practical engineering project. Structural design codes indeed regulate seismic separation requirements for adjacent buildings; however, the risk of building pounding is still high [14]. Moreover, the impact of the pounding effect is not taken into consideration in practical design codes. Consequently, studying pounding between adjacent buildings considering SSSI is very important for the aseismic design of buildings, which could promote structural resistance to earthquake events and help building a sustainable city.

On the basis of a finite element program ANSYS, numerical analysis on pounding effect under seismic loads is presented in this paper. The main objectives are to carry out numerical simulation on the effects of pounding and SSSI phenomena based on a practical engineering project and propose the corresponding computational numerical method, providing a numerical simulation with practical applications in engineering and a reference for future engineering designs.

\section{Model Introduction}

In this numerical simulation, the seismic responses of adjacent shear wall structures on Shanghai soft soil under different foundation conditions are studied considering pounding and SSSI effects. This section gives introduction to the numerical model used in this paper.

\subsection{Superstructure}

The superstructure of the model is a shear wall structure. Figure 1a shows the layout of the standard floor. Table 1 lists the specific parameters of the shear wall structure. The height of the 
standard floor and basement are $3.6 \mathrm{~m}$ and $3 \mathrm{~m}$, respectively. The 20-storey building is called building A while the 27-storey building is called building B. The seismic joint between the adjacent buildings A and B is $0.2 \mathrm{~m}$, which is in accordance with the Chinese seismic design code GB50011-2010 [24].

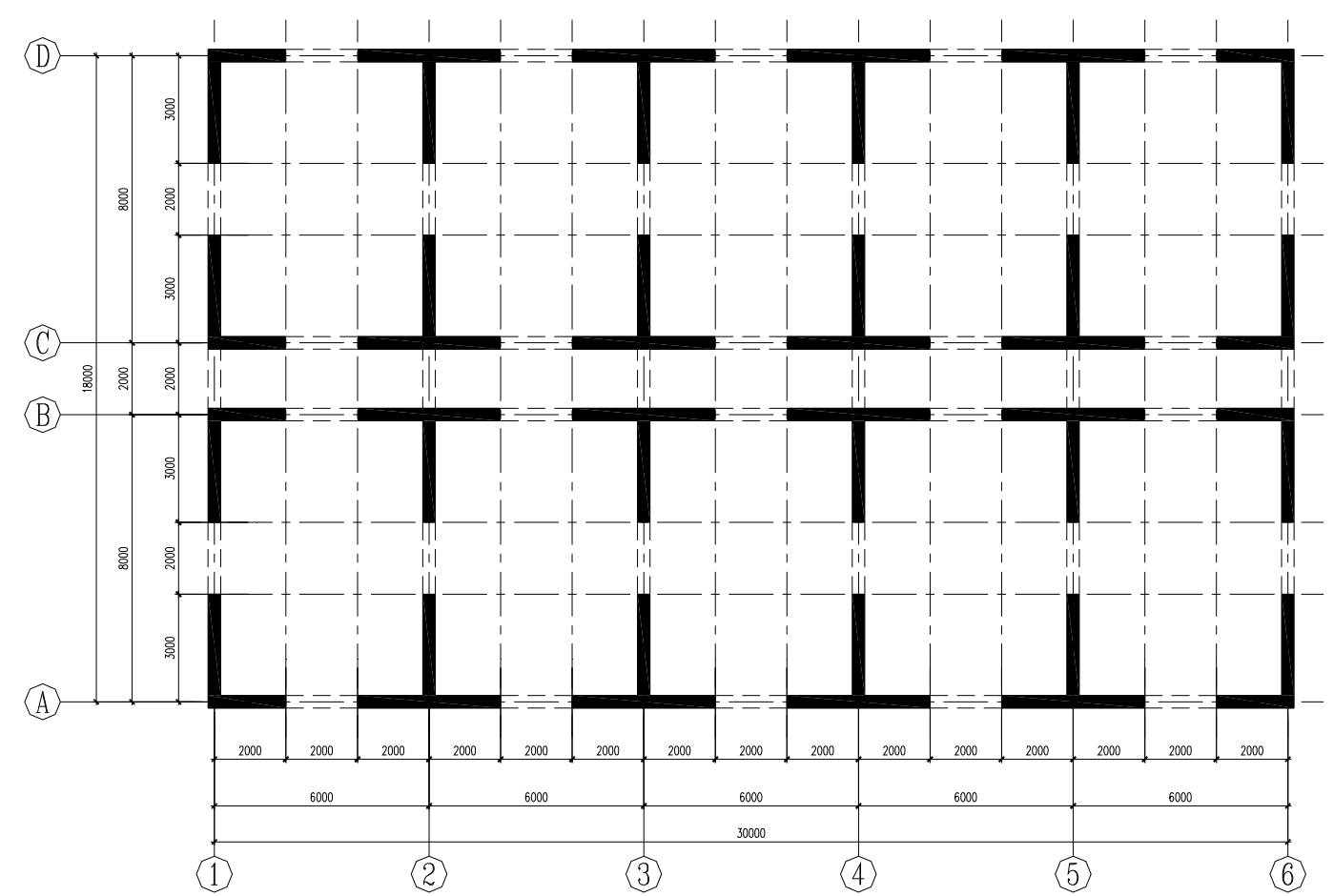

(a)

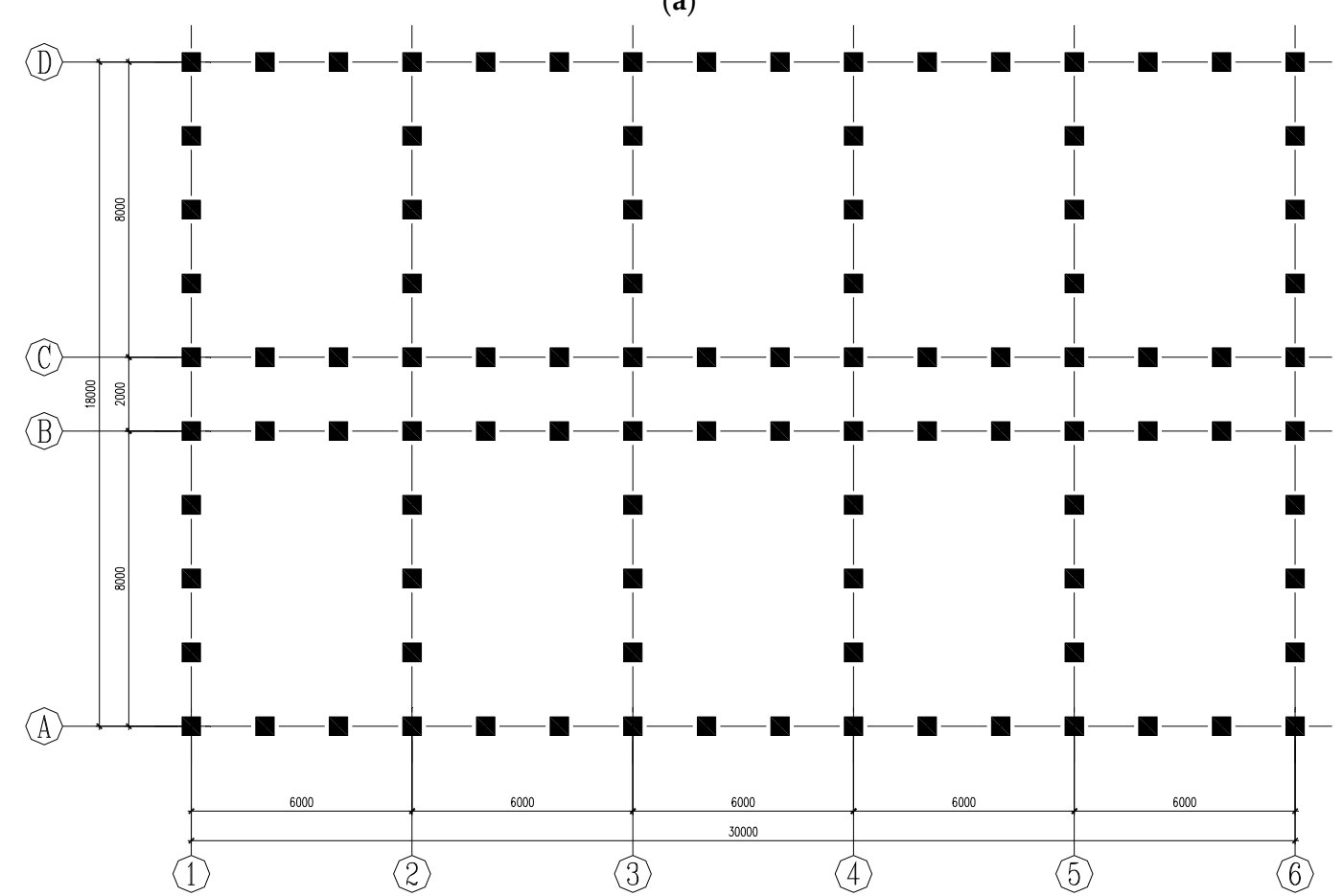

(b)

Figure 1. (a) The layout of shear wall structure; (b) the layout of pile. 
Table 1. Specific parameters of shear wall structures.

\begin{tabular}{ccccccc}
\hline $\begin{array}{c}\text { Name of Standard } \\
\text { Floor }\end{array}$ & $\begin{array}{c}\text { Wall Thickness } \\
(\mathbf{m m})\end{array}$ & $\begin{array}{c}\text { Cross-Section of } \\
\text { Beam }(\mathbf{m m} \times \mathbf{m m})\end{array}$ & $\begin{array}{c}\text { Slab Thickness } \\
(\mathbf{m m})\end{array}$ & $\begin{array}{c}\text { Dead Load } \\
\left(\mathbf{k N} / \mathbf{m}^{\mathbf{2}}\right)\end{array}$ & $\begin{array}{c}\text { Live Load } \\
\mathbf{( k N / \mathbf { m } ^ { 2 } )}\end{array}$ & $\begin{array}{c}\text { Floor } \\
\text { Number }\end{array}$ \\
\hline Basement & 450 & $500 \times 450$ & 120 & 4.5 & 2 & $-2 \sim-1$ \\
First standard floor & 350 & $400 \times 350$ & 120 & 4.5 & 2 & $1 \sim 10$ \\
Second standard floor & 300 & $400 \times 300$ & 120 & 4.5 & 2 & $11 \sim 20$ \\
Third standard floor & 250 & $400 \times 250$ & 120 & 4.5 & 2 & $21 \sim 27$ \\
\hline
\end{tabular}

\subsection{Soil}

The soil of model is the Shanghai soft soil referenced from a geological report. The equivalent shear wave velocity of the ground below $20 \mathrm{~m}$ is $136 \mathrm{~m} / \mathrm{s}$. According to GB50011-2010, it belongs to class IV site, and its parameters are listed in Table 2. 20 times viscoelastic artificial boundary [25] in horizontal direction, 5 times free boundary in longitudinal direction are adopted in numerical analysis (20 and 5 represent the ratio between the calculation range of the soil and the structure size in the same direction, respectively. The direction parallel to the input earthquake is defined as horizontal and the direction perpendicular to the input earthquake is defined as longitudinal).

Table 2. Mechanical and physical parameters of soil.

\begin{tabular}{|c|c|c|c|c|c|c|c|}
\hline $\begin{array}{l}\text { Order of } \\
\text { Soil Layer }\end{array}$ & Name of Soil Layer & $\begin{array}{c}\text { Bottom } \\
\text { Depth (m) }\end{array}$ & $\begin{array}{c}\text { Density } \rho \\
\left(\mathrm{t} / \mathrm{m}^{3}\right)\end{array}$ & $\begin{array}{l}\text { Poisson } \\
\text { Ratio } \gamma\end{array}$ & $\begin{array}{l}\text { Shear Wave } \\
\text { Velocity } v_{s} \\
(\mathrm{~m} / \mathrm{s})\end{array}$ & $\begin{array}{l}\text { Dynamic } \\
\text { Shear } \\
\text { Modulus } \\
G_{d}(\mathrm{MPa})\end{array}$ & $\begin{array}{c}\text { Dynamic } \\
\text { Elastic } \\
\text { Modulus } \\
E_{d}(\mathrm{MPa})\end{array}$ \\
\hline 1 & plain fill & 2.2 & - & - & 107 & - & - \\
\hline 2 & silty clay & 3.8 & 1.86 & 0.3 & 125 & 29.1 & 75.6 \\
\hline 3 & mucky silty clay & 10.3 & 1.76 & 0.35 & 111 & 21.7 & 58.5 \\
\hline 4 & mucky clay & 19.4 & 1.68 & 0.42 & 161 & 43.5 & 123.7 \\
\hline 5 & clay & 25.9 & 1.74 & 0.42 & 214 & 79.7 & 226.3 \\
\hline 6 & silty clay & 29 & 1.96 & 0.25 & 226 & 100.1 & 250.3 \\
\hline $7.1 \mathrm{a}$ & sandy silt & 36.3 & 1.88 & 0.3 & 193 & 70.0 & 182.1 \\
\hline $7.1 \mathrm{~b}$ & silty sand & 58.9 & 1.89 & 0.3 & 274 & 141.9 & 368.9 \\
\hline 8.1 & silty clay & 61.2 & 1.94 & 0.3 & 268 & 139.3 & 362.3 \\
\hline 8.2 & silty clay and clayey silt & 66.7 & 1.9 & 0.3 & 322 & 197.0 & 512.2 \\
\hline 9 & silty sand & $>66.7$ & 1.9 & 0.3 & 298 & 168.7 & 438.7 \\
\hline
\end{tabular}

\subsection{Foundation}

There are three foundation types used in the model, which are the rigid foundation (FIXED), box foundation (BOX) and pile foundation (PILE), respectively. The influence of SSSI is taken into consideration in BOX and PILE. Figure $1 \mathrm{~b}$ displays the layout of pile. The cap thickness of box foundation is $600 \mathrm{~mm}$, and the width of square pile is $500 \mathrm{~mm}$, with length being $34 \mathrm{~m}$. The tip of pile enters into the $7.1 \mathrm{~b}$ silty-sand layer. The calculation depth of soil is $58 \mathrm{~m}$. The superstructure and foundation are made of concrete $C 40$, the elastic modulus of which is $3.25 \times 10^{4} \mathrm{~N} / \mathrm{mm}^{2}$.

\subsection{Earthquake Excitation}

According to Code for seismic design of buildings (GB50011-2010) in China, records of the 1940 El Centro earthquake, 1999 Chichi earthquake and the artificial wave SHW2 wave are selected as the input excitations, labeled EL, CC and SH hereafter. The acceleration time-history and corresponding acceleration response spectra are provided in Figure 2. 


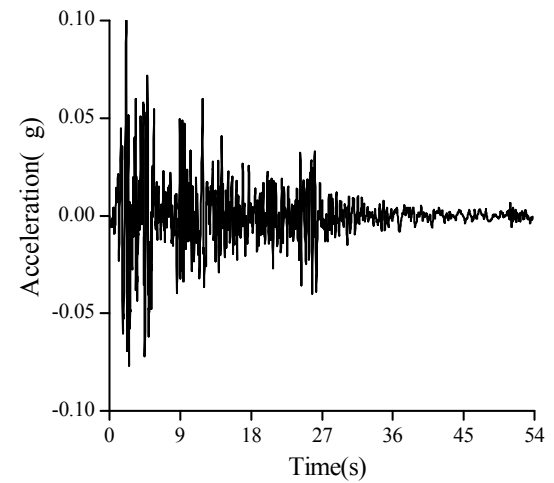

(a)

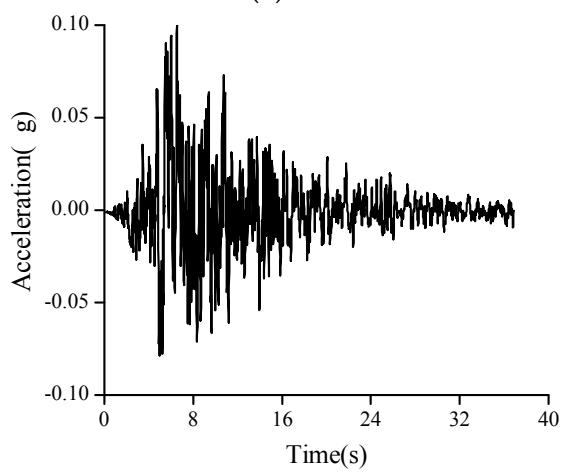

(c)

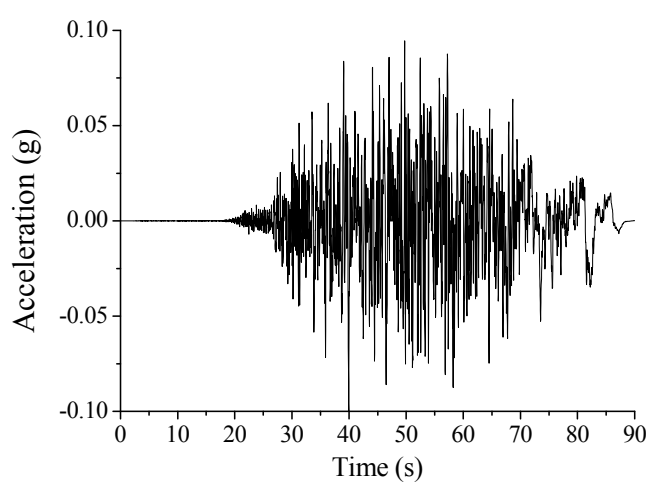

(b)

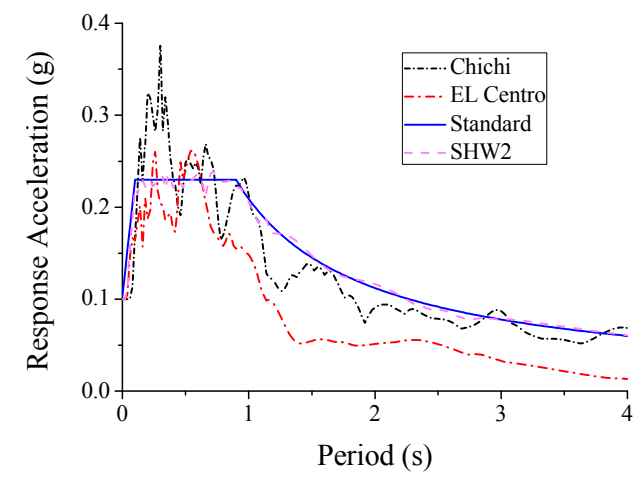

(d)

Figure 2. (a) The acceleration time-history of the El Centro earthquake; (b) the acceleration time-history of the Chichi wave; (c) the acceleration time-history of the SHW2 wave; (d) the acceleration response spectra of the input motions and the design acceleration response spectra.

\section{Key Issues in Simulation}

In the process of establishing the adjacent buildings model considering SSSI and pounding effects, there are many factors that need special considerations. This section gives some key issues in simulation and introduces the determination method of the model parameters. Compared with the traditional seismic design method which only considers fixed foundation, the proposed numerical method can account for both SSSI and pounding effects, hence is an improved one and is valuable for the future seismic design applications.

\subsection{Dynamic Constitutive Model of Soil}

It is feasible to use an equivalent linear model in the model of the dynamic interaction between structure and soil $[26,27]$. The Davidenkov model of the soil skeleton curve is applied in this study, and Equations (1) and (3) depict relationship of $G / G_{\max } \sim \gamma$ and $D / D_{\max } \sim \gamma$, respectively.

$$
\begin{gathered}
\frac{G}{G_{\max }}=1-H(\gamma) \\
H(\gamma)=\left[\frac{\left(|\gamma| / \gamma_{r}\right)^{2 B}}{1+\left(|\gamma| / \gamma_{r}\right)^{2 B}}\right]^{A} \\
\frac{D}{D_{\max }}=\left(1-\frac{G}{G_{\max }}\right)^{\beta}
\end{gathered}
$$

where $G_{\max }$ is the maximum dynamic shear modulus; $D_{\max }$ is the maximum damping ratio; $\gamma_{r}=\tau_{\max } / G_{\max }$ is the reference shear strain; $\tau_{\max }$ is the limit value of the soil shear strength when $\gamma$ 
is large enough; $G_{\max }$ is taken as the dynamic shear modulus obtained from Table 2. $\beta$ is the shape coefficient of $D \sim \gamma$ curve. For Shanghai soft soil, the corresponding statistical empirical values could be regressed from the existing dynamic soil parameters of various soil. It was proved that the model is suitable for seismic response analysis of Shanghai soft soil $[28,29]$. Furthermore, this dynamic model is used in many papers [30,31]. $\beta$ is taken as 1.0 for Shanghai soft soil. $A, B, \gamma_{r}$ can be obtained from Table 3.

$$
\gamma_{\gamma}=\gamma_{\gamma}^{\prime}\left(0.01 \sigma_{m}^{\prime}\right)^{1 / 3}
$$

where $\sigma_{m}^{\prime}$ is the effective confined pressure of soil.

Table 3. Davidenkov model parameters of Shanghai soft soil.

\begin{tabular}{lllll}
\hline Soil Type & $\boldsymbol{A}$ & $\boldsymbol{B}$ & $\boldsymbol{D}_{\max }$ & $\boldsymbol{\gamma}_{\gamma}^{\prime}\left(\mathbf{1 0}^{\mathbf{- 3}}\right)$ \\
\hline cohesive soil & 1.62 & 0.42 & 0.30 & 0.6 \\
silty soil & 1.12 & 0.44 & 0.25 & 0.8 \\
sandy soil & 1.10 & 0.48 & 0.25 & 1.0 \\
medium-coarse sand & 1.10 & 0.48 & 0.25 & 1.2 \\
\hline
\end{tabular}

\subsection{Damping System}

In SSSI model, materials of the soil and the structure are different, and the damping ratio of soil is generally larger than that of the concrete superstructure. Hence, damping is mainly related to material characteristics, and each material' damping should be separately loaded. Rayleigh damping is applied in ANSYS. It is a common knowledge that Rayleigh damping could be obtained using Equation (5):

$$
\xi_{i}=\alpha /\left(2 \omega_{i}\right)+\beta \omega_{i} / 2
$$

where $\alpha$ is the mass damping coefficient, $\beta$ is the stiffness damping coefficient, $\xi_{i}$ is the ratio between actual damping and critical damping in a specific mode of vibration $i$, and $\omega_{i}$ is the natural circular frequency of mode $i$. Additionally, mass damping is almost negligible in most practical structural problems $(\alpha=0)$. In this case, $\beta$ can be evaluated as:

$$
\beta=2 \xi_{i} / \omega_{i}
$$

ANSYS program provides a loading method for material damping only considering the $\beta$ damping, which is consistent with the above consideration. Different damping ratios can be loaded for different materials using this method in the ANSYS program. Li et al. [32] used system identification techniques to obtain the response of soil under pile group foundation condition by shake table test results. The soil damping ratio is achieved through iteration from the $D-\gamma_{d}$ curves [33] based on material property test results [34]. The superstructure' damping ratio is 0.05 .

\subsection{Pounding Impact Simulation}

Contact elements are placed between the adjacent buildings to simulate the pounding phenomena. The contact elements are activated when pounding occurs. Kelvin model is applied in the contact element, which is displayed in Figure $3 a$. $k_{k}$ is a linear stiffness spring, $C_{k}$ is a damper element, in consideration of energy dissipation during pounding. Equation (7) represents the impact force-displacement relation, as shown in Figure $3 b$.

$$
\begin{gathered}
F_{c}=k_{k}\left(u_{1}-u_{2}-g_{p}\right)+c_{k}\left(\dot{u}_{1}-\dot{u}_{2}\right) ; u_{1}-u_{2}-g_{p}>0 \\
F_{c}=0 ; u_{1}-u_{2}-g_{p} \leq 0
\end{gathered}
$$


where $u_{1}$ and $u_{2}$ are the displacements of adjacent buildings, $g_{p}$ is the separation distance between building $\mathrm{A}$ and $\mathrm{B}$. The damping coefficient $C_{k}$ can be determined from the mass and stiffness of the building in pounding case, given by Equation (8). Additionally, the damping coefficient $C_{k}$ could be derived from the restitution coefficient $e$, by equating the energy dissipation in pounding, which is shown in Equation (9):

$$
\begin{aligned}
& c_{k}=2 \xi \sqrt{k_{k} \frac{m_{1} m_{2}}{m_{1}+m_{2}}} \\
& \xi=-\frac{\ln e}{\sqrt{\pi^{2}+(\ln e)^{2}}}
\end{aligned}
$$

where $m_{1}$ and $m_{2}$ are the masses of the pounding buildings, $e$ and $k_{k}$ are taken as 0.65 and $4.38 \times 10^{9} \mathrm{kN} / \mathrm{m}$, respectively [13,35].

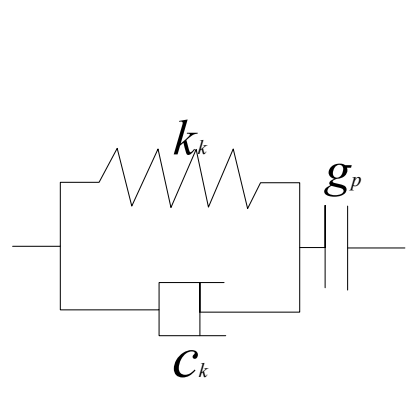

(a)

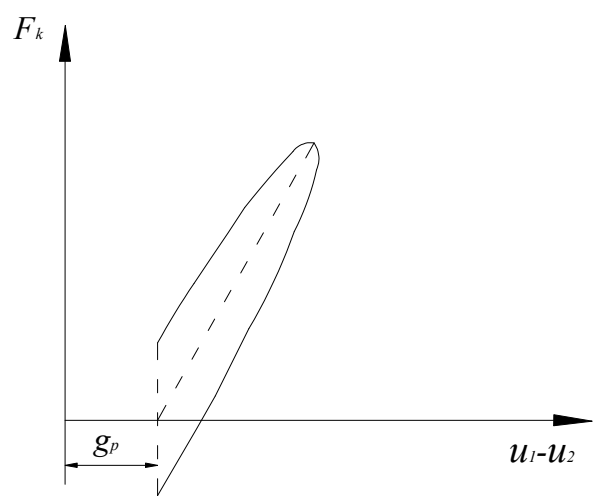

(b)

Figure 3. Impact model. (a) Kelvin model; (b) contact force-displacement relationship of Kelvin model.

\subsection{Element Selection}

In the ANSYS model, three-dimensional SOLID45 elements are used to mesh the cap and soil, while the beams and piles are meshed by using three-dimensional BEAM4 elements, the shear wall and slabs are meshed by using SHELL63 elements. COMBIN40 elements are adopted to simulate the pounding, as presented in Figure 4, and are placed between the 20th floor (the top floor of building A) of building A and B. GAP in the COMBIN40 element is taken as $0.2 \mathrm{~m}$, which is the separation distance between the adjacent buildings. $\mathrm{K} 2$ is taken as $k_{k} . \mathrm{K} 1$ and FSLIDE are taken as $0 . \mathrm{C}$ can be calculated according to Equation (8).

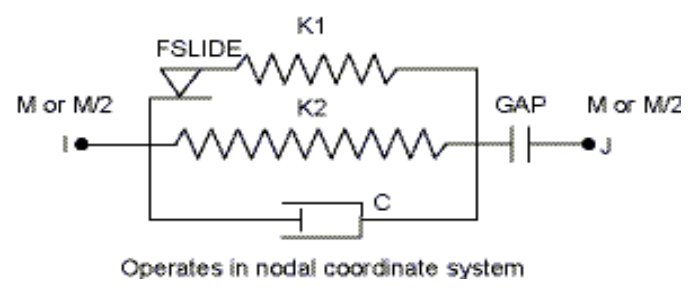

Figure 4. COMBIN40 element.

Furthermore, an appropriate grid size should also be adopted [36]. Figure 5 illustrates the model meshing. 


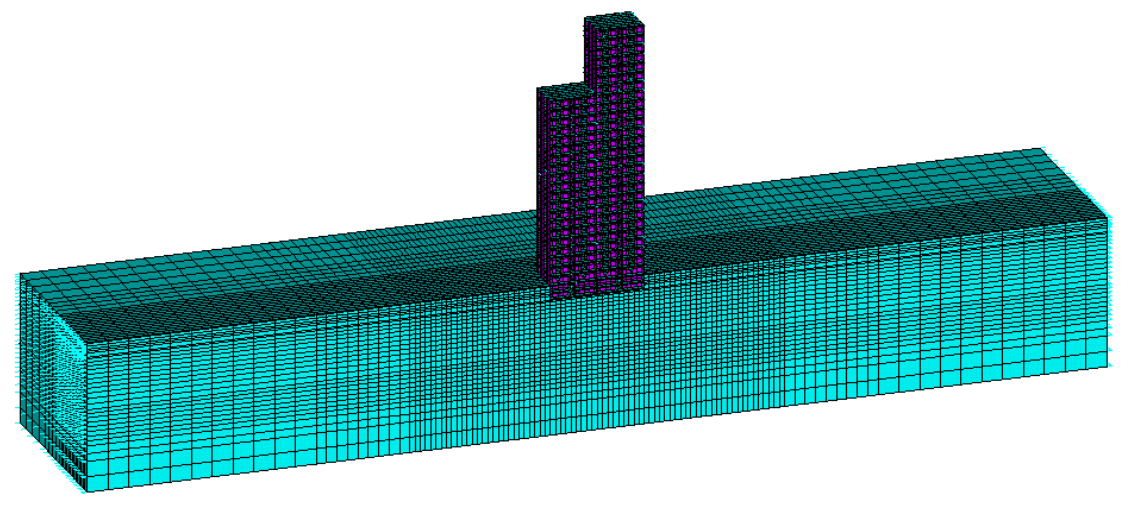

Figure 5. Numerical simulation model.

\section{Simulation Results and Discussions}

Based on the simulation method described in the previous section, several important calculation results are discussed in this section. It is firstly assumed that there is no pounding and the pounding element is not attached, the displacement response of superstructure can be obtained. If the calculated displacement responses of two buildings show the pounding phenomena, which does not accord with the above-mentioned assumptions, namely pounding occurs, the pounding elements are added to re-calculate the dynamic response. In brief, when adjacent buildings pound together, the pounding elements are added, otherwise not added. The dynamic responses of buildings under seismic excitation are studied for the next six cases:

(1) FIXED_N, adjacent buildings with FIXED condition do not pound together.

(2) FIXED_P, adjacent buildings with FIXED condition pound together.

(3) BOX_N, adjacent buildings with BOX foundation do not pound together.

(4) BOX_P, adjacent buildings with BOX foundation pound together.

(5) PILE_N, adjacent buildings with PILE foundation do not pound together.

(6) PILE_P, adjacent buildings with PILE foundation pound together.

As the displacement, acceleration and shear force are very important parameters in seismic design of building structures, for example, the inter-story displacement has close relationship to concrete crack, serviceability of non-structural members, etc.; peak acceleration has close relationship to the comfort of the structure; shear force is related to seismic effects and integral stability of the whole building. Consequently, these three indexes are used to show the structure's overall performance.

\subsection{Displacement Response of Superstructure}

Figures 6-8 show the displacement time-history of the 20th floor of building A and B under different foundation conditions. The excitations in Figures 6-8 are El Centro wave, Chichi wave and SHW2 wave, respectively. Figure 9 presents the peak inter-story displacement and the peak inter-story displacement ratio of building B under different foundation conditions and SHW2 wave. Note that the peak inter-story displacement ratio of each floor refers to the ratio of its peak inter-story displacement in the pounding case compared to its peak inter-story displacement in the no-pounding case. This index evaluates the situation of structural design based on the current code. In current design code, the pounding effect is not considered. Consequently, if this index is larger than one, it indicates that the present code based design tends to be dangerous; while if this is less than one, it indicates that the present code based design is conservative.

From these figures, it can be found that:

(1) Under El Centro wave (EL), there is no pounding under the condition of FIXED and BOX (Figure 6a,b); however, pounding occurs under the condition of PILE (Figure 6c). Hence, 
the pounding elements are added to re-calculate the responses, which is shown in Figure $6 \mathrm{~d}$. Under Chichi wave (CC), there is no pounding under the condition of FIXED (Figure 7a) while pounding occurs under the condition of BOX and PILE (Figure $7 \mathrm{~b}, \mathrm{~d}$ ). The corresponding structural responses considering pounding effects are shown in Figure $7 \mathrm{c}, \mathrm{e}$. Under the excitation of SHW2 wave (SH), pounding occurs under the condition of FIXED, BOX and PILE (Figure 8a-e), and the displacement time-history changes because of the pounding behavior (Figure $8 \mathbf{b}, \mathrm{d}, \mathrm{f}$ ). Thus, it can be seen that different forms of foundation and different excitations yield different displacement responses of the superstructure, and pounding phenomena may occur.

(2) The peak inter-story displacement ratios of building B under FIXED condition are almost one, while that for BOX and PILE are variable. This is related to the degree of pounding effect. As shown in Figure 8a, the displacement time histories of two buildings are slightly crossing, leading to slightly impact. However, as illustrated in Figure $8 \mathrm{c}, \mathrm{e}$, the two displacement curves are heavily crossed at many time instants, indicating severe impacts, thus resulting in variable changes of the original calculated response in the no-pounding case. However, the impact of the pounding and SSSI effects is very complex, because there is no uniform law for the BOX and PILE situations. These effects are not always leading to a dangerous result as shown in BOX case. This may be related to the out of phase lateral vibrations under different conditions.

(3) Although the pounding effects are variable under different foundation conditions, the occurrence of pounding phenomena imply that the seismic separation requirement for adjacent buildings in Chinese design code may not be enough to avoid pounding phenomena considering SSSI effect. In another word, the current design tends to be dangerous in some cases. It implies that pounding effects should be taken into account in seismic design, which is very crucial for national sustainable development, especially in earthquake prevention and disaster reduction.

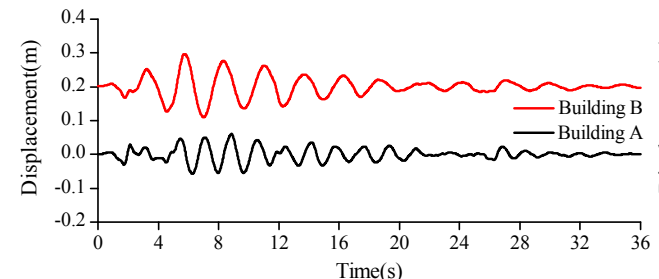

(a)

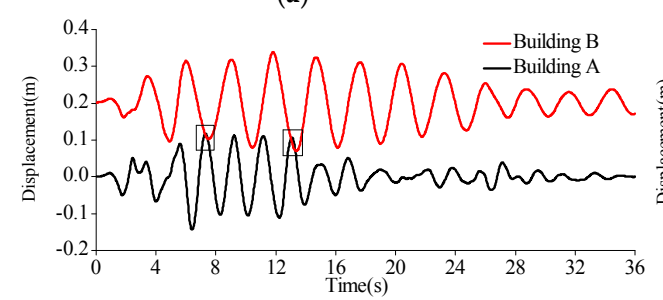

(c)

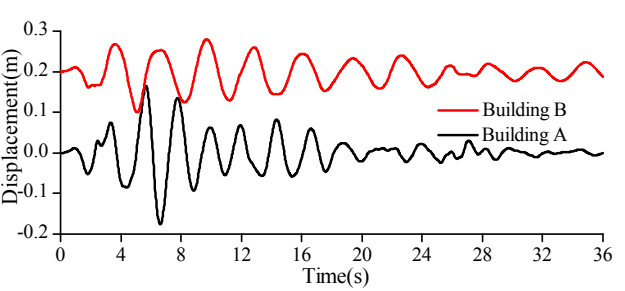

(b)

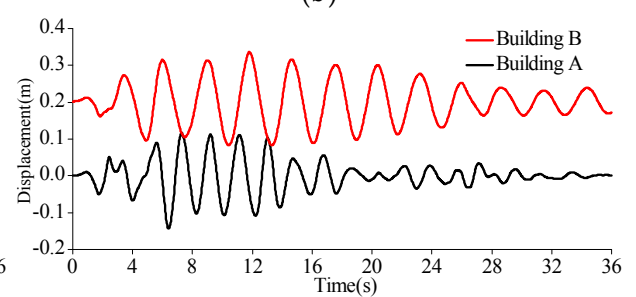

(d)

Figure 6. The displacement time-history of the 20th floor of building A and B (EL). (a) FIXED_N; (b) BOX_N; (c) PILE_N; (d) PILE_P.

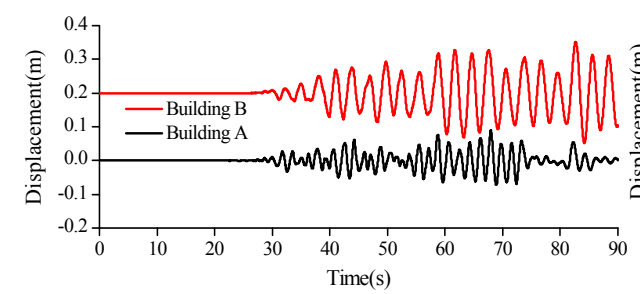

(a)

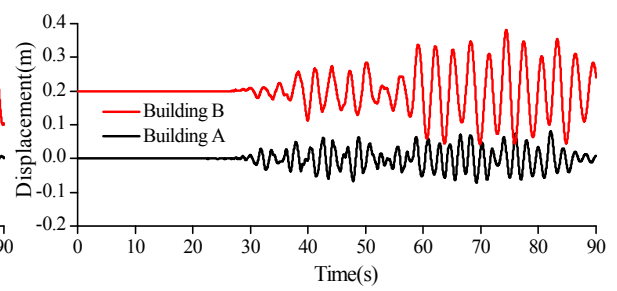

(b)

Figure 7. Cont. 


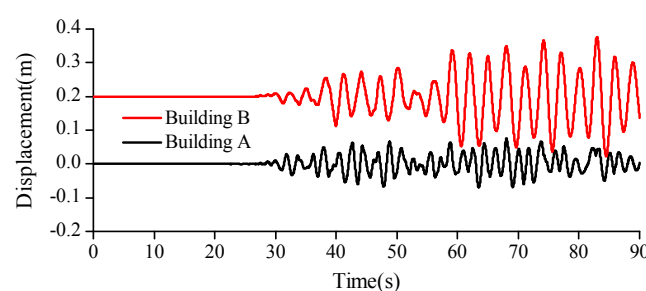

(c)

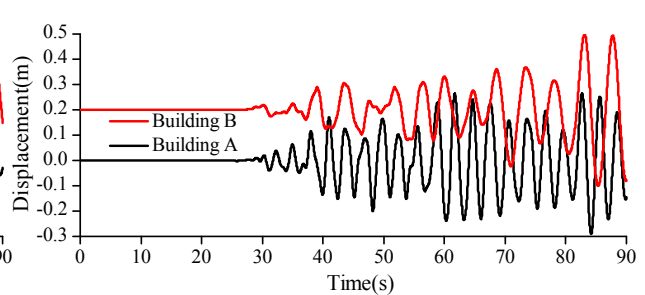

(d)

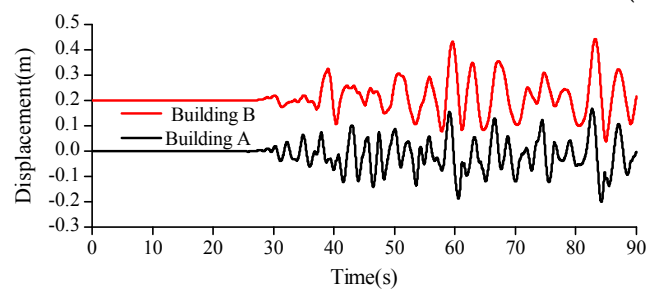

(e)

Figure 7. The displacement time-history of the 20th floor of building A and B (CC). (a) FIXED_N; (b) BOX_N; (c) BOX_P; (d) PILE_N; (e) PILE_P.

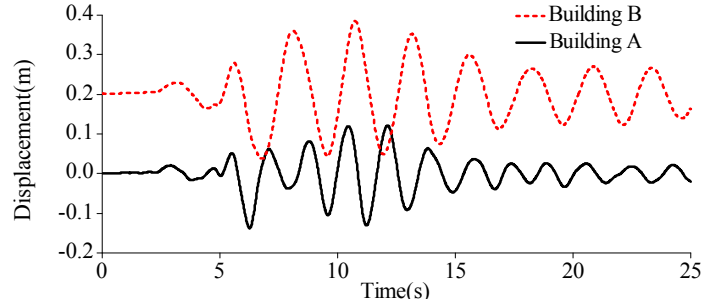

(a)

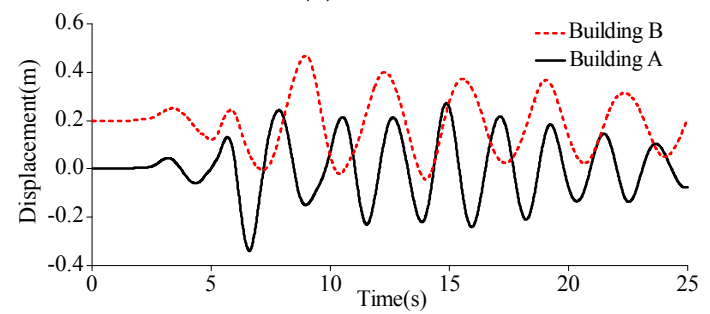

(c)

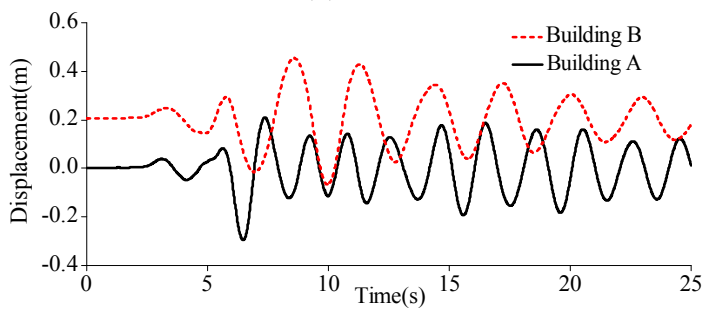

(e)

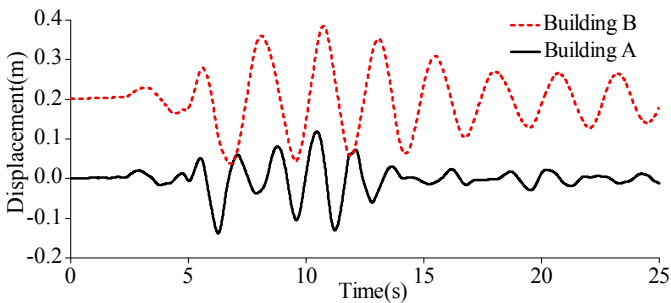

(b)

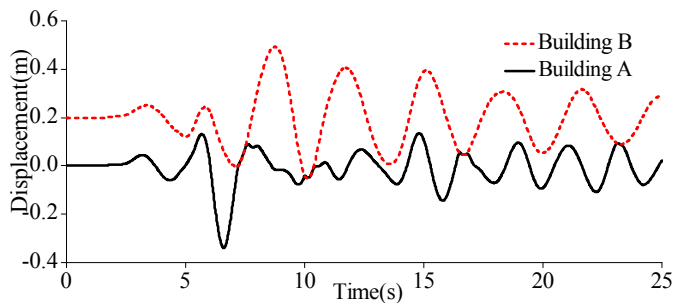

(d)

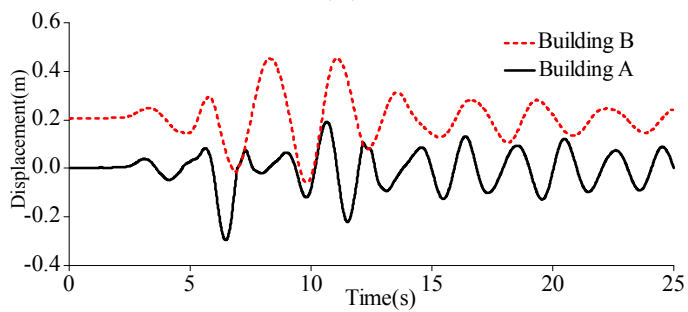

(f)

Figure 8. The displacement time-history of the 20th floor of building A and B (SH). (a) FIXED_N; (b) FIXED_P; (c) BOX_N; (d) BOX_P; (e) PILE_N; (f) PILE_P. 


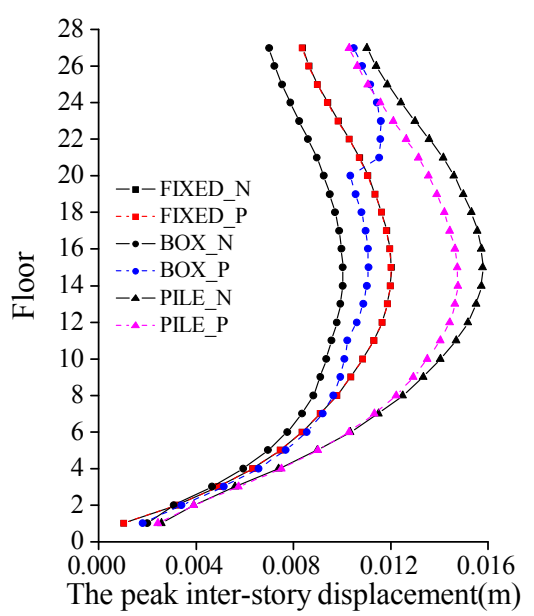

(a)

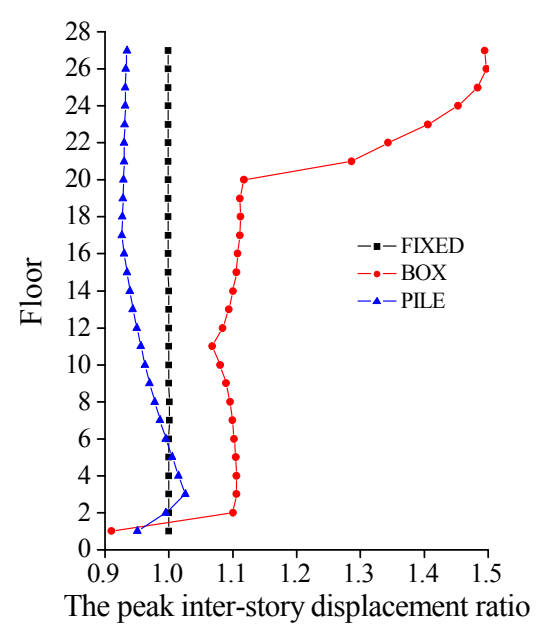

(b)

Figure 9. (a) The peak inter-story displacement of building B (SH); (b) the peak inter-story displacement ratio of building $\mathrm{B}(\mathrm{SH})$.

\subsection{Acceleration Response of Superstructure}

Figure 10 plots the peak acceleration and the peak acceleration ratio of building A and B under SHW2 excitation. Note that the peak acceleration ratio of each floor refers to the ratio of its peak acceleration in the pounding case compared to its peak acceleration in the no-pounding case. The physical meaning of this index is similar to the peak inter-story displacement ratio explained in the above section. The acceleration time-history and corresponding amplitude spectrum at the top floor of building $\mathrm{A}$ and $\mathrm{B}$ are plotted in Figure 11. The following observations can be made from these figures:

(1) The peak acceleration is amplified in pounding case under three types of foundation compared with no pounding case, as shown in Figure $10 \mathrm{~b}, \mathrm{~d}$ that the peak acceleration ratios of building $\mathrm{A}$ and $\mathrm{B}$ are more than one. The peak acceleration of the floor near the pounding floor is enlarged, but the peak acceleration of the floor far away from the pounding floor is almost unchanged. The closer to the pounding floor, the greater the degree of amplification, and the amplification reaches the largest at the pounding floor. This is because after stress redistribution, the impact of pounding on acceleration response gradually decreases as the distance to the pounding floor increases.

(2) The short duration and high magnitude of acceleration pulses are caused by pounding at 20th floor of building A. It is observed that higher frequency content of acceleration increases at 20th floor of building A from Figure 11b,d,f, which is consistent to the conclusion by Chouw [37].

(3) The acceleration response of PILE_P considering SSSI in pounding case, is greater than that of FIXED_P, which does not take SSSI into consideration in the pounding case. Therefore, SSSI amplifies the acceleration response caused by pounding.

(4) The impact of pounding on the acceleration response of building A (stiff building) is greater than that of building B (flexible building). 


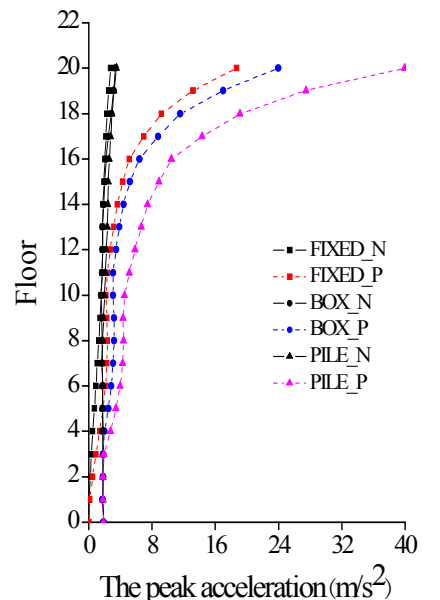

(a)

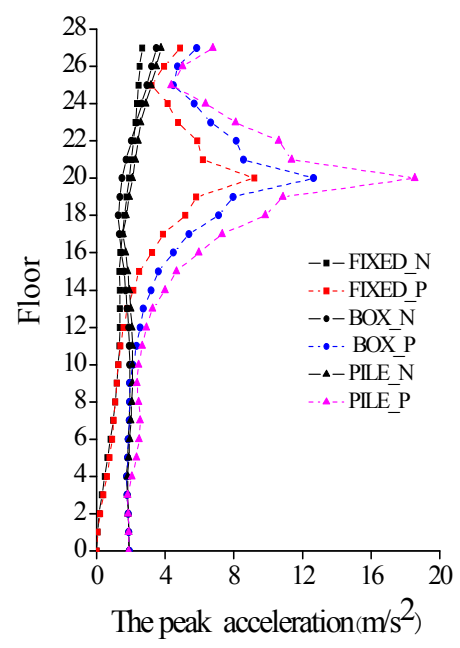

(c)

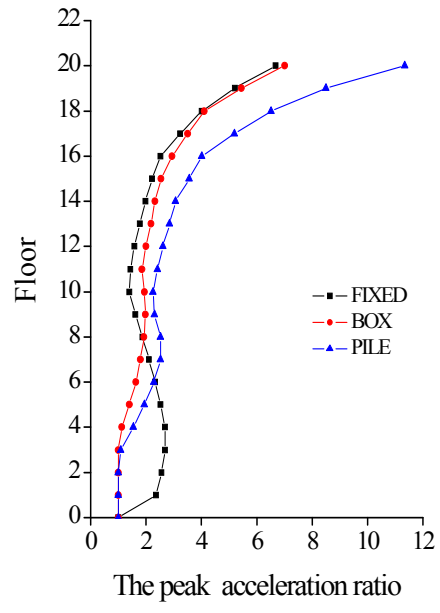

(b)

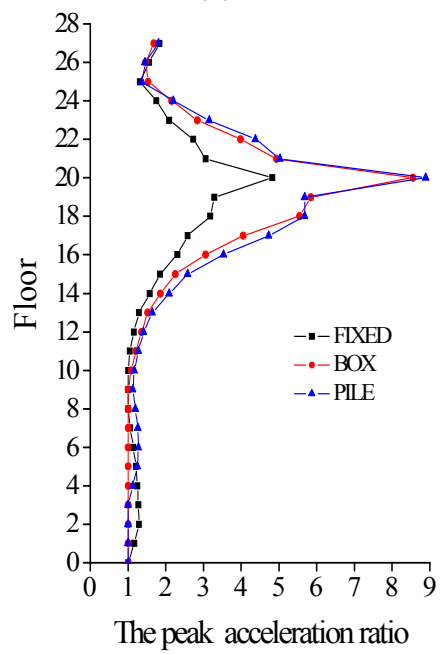

(d)

Figure 10. The peak acceleration (SH): (a) building A; (c) building B; The peak acceleration ratio (SH): (b) building A; (d) building B.

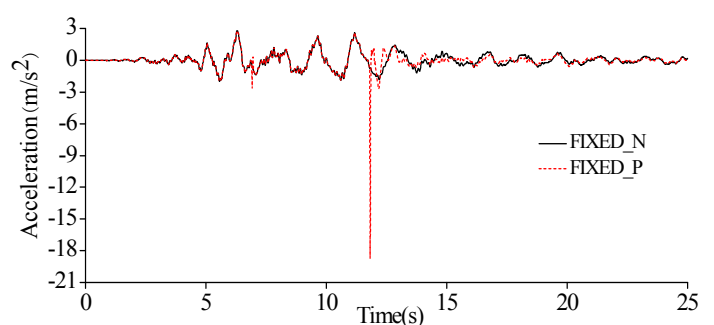

(a)

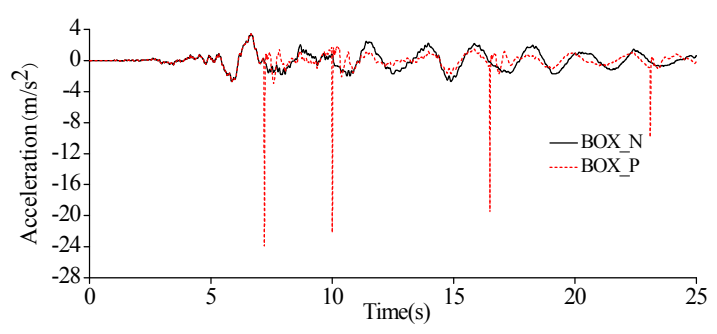

(c)

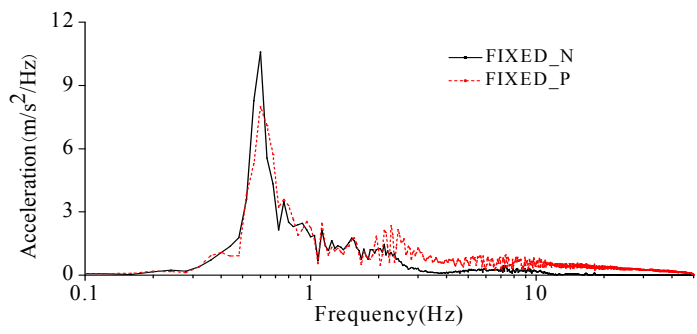

(b)

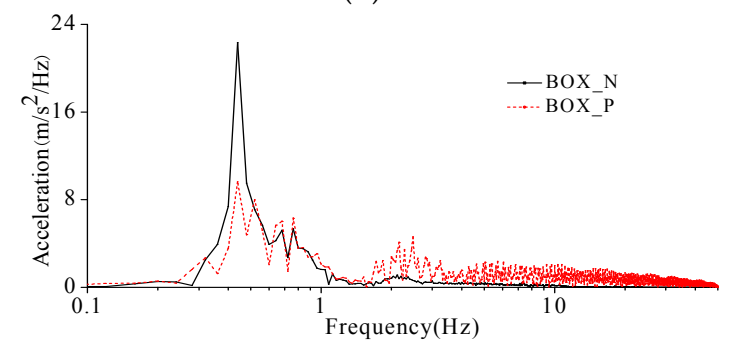

(d)

Figure 11. Cont. 


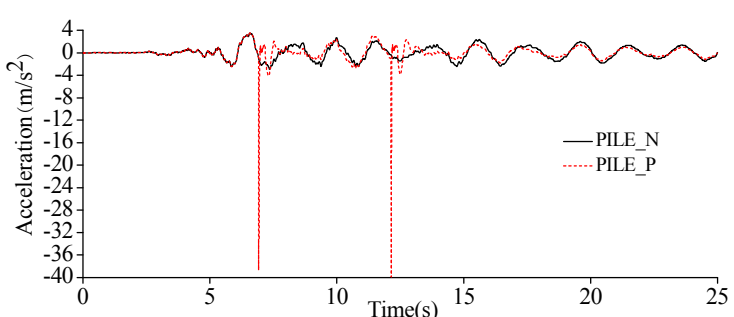

(e)

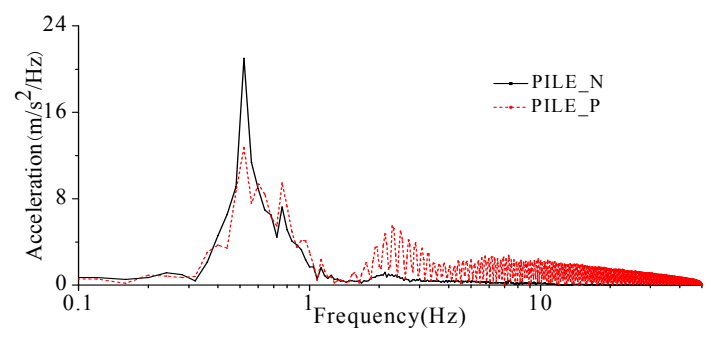

(f)

Figure 11. The acceleration time-history at 20th floor of building A: (a) FIXED; (c) BOX; (e) PILE; The corresponding amplitude spectrum at 20th floor of building A: (b) FIXED; (d) BOX; (f) PILE.

\subsection{Shear Response of Superstructure}

Under SHW2 excitation, Figure 12 displays the peak inter-story shear and the peak inter-story shear ratio of building A and B. Note that the peak inter-story shear ratio of each floor refers to the ratio of its peak inter-story shear in the pounding case compared to its peak inter-story shear in the no-pounding case, with the similar physical meaning as that of displacement and acceleration. From these figures, some interesting phenomena are observed.

(1) Pounding amplifies the shear response as shown in Figure $12 b$,d that the peak inter-story shear ratios of building $\mathrm{A}$ and $\mathrm{B}$ are more than one. The peak inter-story shear of the floor near the pounding floor is enlarged, but the peak inter-story shear of the floor far away from the pounding floor is almost unchanged. As the distance to the pounding floor increases, as a result of stress redistribution, the impact of pounding on shear response and the degree of amplification gradually decrease, and the amplification reaches the largest at the pounding floor.

(2) The shear responses of PILE_P taking SSSI into consideration in pounding case, is greater than that of FIXED_P, which does not take SSSI into consideration in pounding case. SSSI amplifies the shear response due to pounding.

(3) The impact of pounding on the shear response of building A (stiff building) is greater than that of building B (flexible building).

(4) Excessive peak inter-story shear may lead to integral instability and overturning of structure. The effects of pounding and SSSI phenomena should be taken into consideration in future engineering designs.

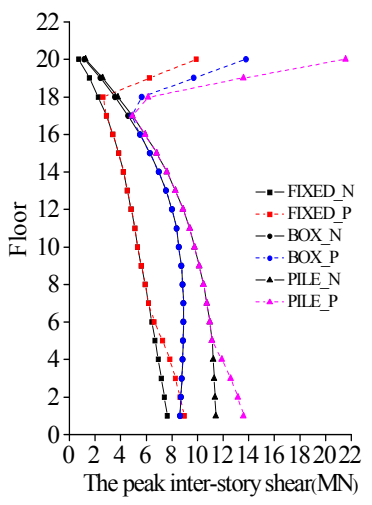

(a)

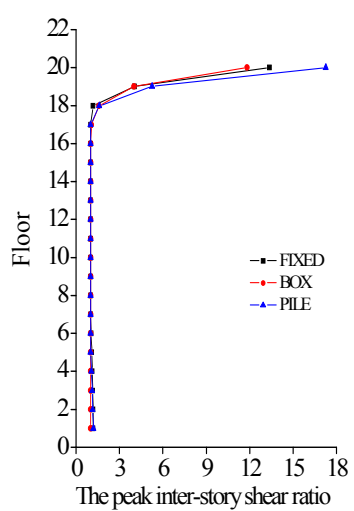

(b)

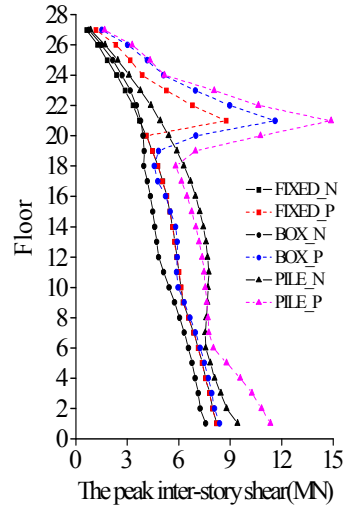

(c)

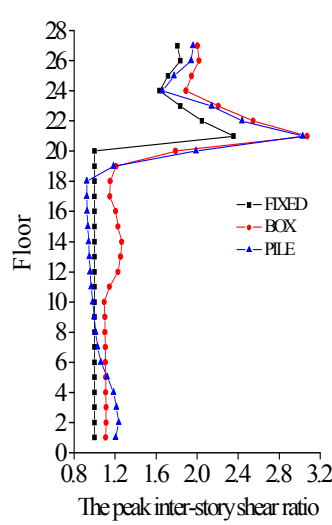

(d)

Figure 12. The peak inter-story shear: (a) building A; (c) building B; The peak inter-story shear ratio: (b) building A; (d) building B. 


\section{Conclusions and Significance}

\subsection{Conclusions}

Based on a practical engineering project, this paper presents a three-dimensional finite element numerical simulation method using ANSYS software. Followed by the Chinese seismic design code, three earthquake inputs are chosen. Under the El Centro wave, Chichi wave and the SHW2 wave, the dynamic responses of the adjacent shear wall structure with the rigid foundation, box foundation and pile foundation are calculated respectively, in case of pounding or no pounding. The following are some conclusions drawn from this study, which can provide reference for future engineering designs:

(1) From the displacement response of superstructure, it can be seen that different forms of foundation and different excitations yield different displacement responses of the superstructure, and pounding phenomena may occur. As a result of pounding effect, the peak floor displacement of building changes. It may increase or decrease due to out of phase lateral vibrations. The occurrence of pounding illustrates that the seismic separation requirement for adjacent buildings in Chinese seismic design code may not be enough to avoid pounding phenomena.

(2) Pounding amplifies the peak acceleration and the peak inter-story shear force. The closer to the pounding floor, the greater the degree of amplification, and it reaches the largest at the pounding floor. The short duration and high magnitude of acceleration pulses are caused by pounding at pounding floor. It is observed that higher frequency contents of acceleration increases at pounding floor. In short, pounding worsens the adjacent buildings' dynamic responses.

(3) SSSI negatively influences the seismic responses of buildings in pounding since the seismic response considering SSSI is larger than that of the fixed base condition. In practical engineering, ignoring the effects of pounding and SSSI may lead to erroneous and unconservative design. The designer should take SSSI into consideration in the building design and pounding effects should also be considered to create a reliable design. It is very crucial for national sustainable development, especially in earthquake prevention and disaster reduction.

\subsection{Significance}

Through the numerical simulation, it can be found that the seismic separation requirement for adjacent buildings in Chinese design code may not be enough to avoid pounding phenomena considering SSSI effect, and pounding worsens the adjacent buildings' dynamic responses. As mentioned above, structural damage due to pounding is often serious or irreparable. In addition, tremendous losses on economy and people's lives, etc. may be caused by pounding. All this poses serious challenges to the sustainability of country.

Recently, the Chinese government has put forward a new plan entitled "Resilient City" to improve the capacity of earthquake prevention and disaster reduction, and promote the construction of sustainable city. One of its primary tasks is to study the theory and method of aseismic design in order to meet the seismic resilience demand of complex urban system and major industrial facilities. This paper provides a numerical simulation with practical applications in engineering and a reference for future engineering designs, in terms of computational numerical method and results. According to the plan, this numerical method not only fully meets the demands, but also contributes to sustainable development of China. On the other hand, it could also encourage and support the other engineering resilient technologies, such as design techniques of seismic reduction and energy dissipation with dampers, new method for seismic reinforcement of existing buildings, and rapid recovery technology of post-earthquake, etc. In summary, studying the pounding between adjacent buildings considering SSSI is of vital significance to the sustainability of the whole country.

However, it should also be admitted that the studies on structural dynamic performance considering both pounding and SSSI effects under seismic loads are quite complex. This paper 
only provides a glimpse on such a problem and gives some references to engineering designs. Further study is still in progress.

Acknowledgments: This project was supported as a project of the National Natural Science Foundation of China (Grant No. 51478355).

Author Contributions: Peizhen Li proposed the simulation method and wrote the paper; Shutong Liu performed the calculation and analyzed the data; Zheng Lu conceived the analytical method, provided valuable discussions and revised the paper.

Conflicts of Interest: The authors declare no conflict of interest.

\section{References}

1. Kasai, K.; Maison, B.F. Building pounding damage during the 1989 Loma Prieta earthquake. Eng. Struct. 1997, 19, 195-207. [CrossRef]

2. Cole, G.L.; Dhakal, R.P.; Carr, A.J.; Bull, D. Interbuilding pounding damage observed in the 2010 Darfield earthquake. Bull. N. Z. Soc. Earthq. Eng. 2010, 43, 382-386.

3. Cole, G.; Dhakal, R.P.; Turner, F.M. Building pounding damage observed in the 2011 Christchurch earthquake. Earthq. Eng. Struct. Dyn. 2014, 41, 893-913. [CrossRef]

4. Lu, Z.; Wang, D.C.; Masri, S.F.; Lu, X.L. An experimental study of vibration control of wind-excited high-rise buildings using particle tuned mass dampers. Smart Struct. Syst. 2016, 18, 93-115. [CrossRef]

5. Lu, Z.; Chen, X.Y.; Zhang, D.C.; Dai, K.S. Experimental and analytical study on the performance of particle tuned mass dampers under seismic excitation. Earthq. Eng. Struct. Dyn. 2017, 46, 697-714. [CrossRef]

6. Lu, Z.; Lu, X.L.; Jiang, H.J.; Masri, S.F. Discrete element method simulation and experimental validation of particle damper system. Eng. Comput. 2014, 31, 810-823. [CrossRef]

7. Dai, K.S.; Wang, J.Z.; Mao, R.F.; Lu, Z.; Chen, S.E. Experimental investigation on dynamic characterization and seismic control performance of a TLPD system. Struct. Des. Tall Spec. Build. 2017, 26, e1350. [CrossRef]

8. Lu, Z.; Wang, Z.X.; Masri, S.F.; Lu, X.L. Particle Impact Dampers: Past, Present, and Future. Struct. Control Health Monit. 2017. [CrossRef]

9. Lu, Z.; Chen, X.Y.; Zhou, Y. An equivalent method for optimization of particle tuned mass damper based on experimental parametric study. J. Sound Vib. 2017. [CrossRef]

10. Lu, Z.; Huang, B.; Zhou, Y. Theoretical study and experimental validation on the energy dissipation mechanism of particle dampers. Struct. Control Health Monit. 2017. [CrossRef]

11. Lu, Z.; Chen, X.Y.; Lu, X.L.; Yang, Z. Shaking table test and numerical simulation of an RC frame-core tube structure for earthquake-induced collapse. Earthq. Eng. Struct. Dyn. 2016, 45, 1537-1556. [CrossRef]

12. Anagnostopoulos, S.A. Equivalent viscous damping for modeling inelastic impacts in earthquake pounding problems. Earthq. Eng. Struct. Dyn. 2004, 33, 897-902. [CrossRef]

13. Muthukumar, S.; DesRoches, R. A Hertz contact model with non-linear damping for pounding simulation. Earthq. Eng. Struct. Dyn. 2006, 35, 811-828. [CrossRef]

14. Naserkhaki, S.; Aziz, F.N.A.A.; Pourmohammad, H. Earthquake induced pounding between adjacent buildings considering soil-structure interaction. Earthq. Eng. Eng. Vib. 2012, 11, 343-358. [CrossRef]

15. Naderpour, H.; Barros, R.C.; Khatami, S.M.; Jankowski, R. Numerical study on pounding between two adjacent buildings under earthquake excitation. Shock Vib. 2016. [CrossRef]

16. Padron, L.A.; Aznarez, J.J.; Maeso, O. Dynamic structure-soil-structure interaction between nearby piled buildings under seismic excitation by BEM-FEM model. Soil Dyn. Earthq. Eng. 2009, 29, 1084-1096. [CrossRef]

17. Ghergu, M.; Ionescu, I.R. Structure-soil-structure coupling in seismic excitation and "city effect". Int. J. Eng. Sci. 2009, 47, 342-354. [CrossRef]

18. Alamo, G.M.; Padron, L.A.; Aznarez, J.J.; Maeso, O. Structure-soil-structure interaction effects on the dynamic response of piled structures under obliquely incident seismic shear waves. Soil Dyn. Earthq. Eng. 2015, 78, 142-153. [CrossRef]

19. Madani, B.; Behnamfar, F.; Riahi, H.T. Dynamic response of structures subjected to pounding and structure-soil-structure interaction. Soil Dyn. Earthq. Eng. 2016, 78, 46-60. [CrossRef] 
20. Filiatrault, A.; Wagner, P.; Cherry, S. Analytical prediction of experimental building pounding. Earthq. Eng. Struct. Dyn. 1995, 24, 1131-1154. [CrossRef]

21. Chau, K.T.; Wei, X.X.; Guo, X.; Shen, C.Y. Experimental and theoretical simulations of seismic poundings between two adjacent structures. Earthq. Eng. Struct. Dyn. 2003, 32, 537-554. [CrossRef]

22. Rezavandi, A.; Moghadam, A.S. Experimental and numerical study on pounding effects and mitigation techniques for adjacent structures. Adv. Struct. Eng. 2007, 10, 121-134. [CrossRef]

23. Jankowski, R. Experimental study on earthquake-induced pounding between structural elements made of different building materials. Earthq. Eng. Struct. Dyn. 2010, 39, 343-354. [CrossRef]

24. CMC (China Ministry of Construction). Code for Seismic Design of Buildings (GB50011-2010); China Architecture \& Building Press: Beijing, China, 2010. (In Chinese)

25. Deeks, A.J.; Randolph, M.F. Axisymmetric time-domain transmitting boundaries. J. Eng. Mech. 1994, 120, 25-42. [CrossRef]

26. Martin, P.P.; Seed, H.B. One-dimensional dynamic ground response analyses. J. Geotech. Eng. Div. ASCE 1982, 8, 935-952. [CrossRef]

27. Hadjian, A.H.; Tseng, W.S.; Chang, C.Y.; Anderson, D.; Tsai, N.C.; Tang, Y.K.; Tang, H.T.; Stepp, J.C. The learning from the large scale from Lotung soil-structure interaction experiments (I). World Earthq. Eng. 1993, 3, 41-52.

28. Huang, Y.; Chen, Z.C.; Zhou, H.B. Dynamic calculation model of Shanghai soft soil. J. Tongji Univ. 2000, 28, 359-363.

29. Huang, Y.; Ye, W.M.; Tang, Y.Q. Dynamic coupled analysis for earthquake response of pile foundations. Int. Deep Found. Congr. 2002, 396-404. [CrossRef]

30. Lou, M.L.; Li, Y.C.; Li, N.S.; Wen, F. Some problems in seismic response analysis of soil layer with deep deposit. J. Tongji Univ. 2006, 34, 427-432.

31. Lu, X.L.; Li, P.Z.; Chen, B.; Chen, Y.Q. Computer simulation of the dynamic layered soil-pile-structure interaction system. Can. Geotech. J. 2005, 42, 742-751. [CrossRef]

32. Li, P.Z.; Yang, J.P.; Lu, Z.; Lu, X.L. Response of liquefiable soils in pile group foundations of tall buildings from shaking table tests. J. Asian Archit. Build. Eng. 2016, 15, 311-318. [CrossRef]

33. Li, P.Z.; Hou, X.Y.; Liu, Y.M.; Lu, X.L. Shaking table model tests on dynamic structure-soil-structure interaction during various excitations. In Proceedings of the 15th World Conference on Earthquake Engineering, Lisbon, Portugal, 23-28 September 2012.

34. Lu, X.L.; Li, P.Z.; Chen, B.; Chen, Y.Q. Numerical analysis of dynamic soil-box foundation-structure interaction system. J. Asian Archit. Build. Eng. 2002, 1, 9-14. [CrossRef]

35. Fan, J.; Lin, T.; Wei, J.J. Response and protection of the impact of base-friction-isolated structures and displacement-constraint devices under near-fault earthquakes. China Civ. Eng. J. 2007, 40, 10-16.

36. Li, P.Z.; Zhao, P.; Lu, X.L. Parameter identification and analysis of shaking table tests on SSI system. J. Asian Archit. Build. Eng. 2011, 10, 421-428. [CrossRef]

37. Chouw, N. Influence of soil-structure interaction on pounding response of adjacent buildings due to near-source earthquakes. J. Appl. Mech. 2002, 5, 543-553. [CrossRef]

(C) 2017 by the authors. Licensee MDPI, Basel, Switzerland. This article is an open access article distributed under the terms and conditions of the Creative Commons Attribution (CC BY) license (http://creativecommons.org/licenses/by/4.0/). 